\title{
Expression of miR-15a and miR-16-1 in patients with chronic lymphocytic leukemia
}

\author{
Lenka Humplikova ${ }^{a}$, Sona Kollinerova ${ }^{b}$, Tomas Papajika, Zuzana Pikalovaa ${ }^{a}$ Milena Holzerovaa ${ }^{a}$, Vit Prochazkaa, \\ Martina Divoka ${ }^{a}$, Martin Modriansky ${ }^{b}$, Karel Indraka, Marie Jarosova ${ }^{a}$
}

\begin{abstract}
Introduction. MicroRNAs (miRNAs) are small non-coding single-stranded RNA molecules that regulate gene expression at the post-transcriptional level. In the pathogenesis of chronic lymphocytic leukemia (CLL), miR-15a and miR-16-1 play an important role. These miRNAs are located on chromosome 13 in the 13q14.3 region, which is deleted in more than $55 \%$ of CLL patients. This aberration affects expression of miRNAs.

Objectives. The study aimed at performing a molecular genetic analysis of miR-15a and miR-16-1 expression in a group of 39 patients diagnosed with CLL and determining the association between the expression of the two miRNAs and types of deletions in the $13 q 14$ region.

Methods. We used fluorescence in situ hybridiziation (FISH) for determination of mono- or biallelic deletion $13 q$ and quantitative polymerase chain reaction (Q-RT-PCR) to revealed expression miR-15a and miR-16-1 in 39 patients suffering from CLL.

Results. The analysis comprised 19 patients with monoallelic 13q14 deletion, 3 patients with biallelic deletion, 9 patients with both monoallelic and biallelic deletions, and 8 patients without $13 q 14$ deletion serving as controls. The results showed different levels of miRNA expression in individual patients. Significantly higher normalized levels of miR-15a expression were found in the control group and patients with monoallelic 13q14 expression compared with patients with biallelic deletion. There was a significantly decreased expression of both miRNAs in patients with biallelic deletion of the $13 q 14$ region but only when deletions were present in $77 \%$ or more of cells, as detected by fluorescent in situ hybridization (FISH).
\end{abstract}

Key words: chronic lymphocytic leukemia, microRNA, miRNA expression, fluorescence in situ hybridization,13q14 deletion, monoallelic deletion, biallelic deletion

Received: January 8, 2013; Accepted: July 19, 2013; Available online: September 5, 2013 http://dx.doi.org/10.5507/bp.2013.057

${ }^{a}$ Department of Hemato-Oncology, Faculty of Medicine and Dentistry, Palacky University Olomouc, Czech Republic ${ }^{b}$ Department of Medical Chemistry and Biochemistry, Faculty of Medicine and Dentistry, Palacky University Olomouc Corresponding author: Marie Jarosova, e-mail: marie.jarosova@fnol.cz

\section{INTRODUCTION}

Chronic lymphocytic leukemia (CLL) is the most common type of hematological malignancy diagnosed in adults in the Western hemisphere. This condition is characterized by the accumulation of mature-looking $\mathrm{B}$ cells with CD19+/CD20+/CD23+ immunophenotypes and aberrant expression of the CD5 marker. Currently, little is still known about the molecular mechanisms responsible for the expansion of leukemic clones and the development of CLL. Defects in both apoptosis and the proliferation of $\mathrm{B}$ cells are involved in the pathogenesis of CLL (ref. ${ }^{1-3}$ ). The clinical manifestations of the disease are heterogeneous, ranging from indolent to aggressive, rapidly progressing forms. The prognosis of patients with CLL is determined by various biological parameters, such as immunoglobulin heavy chain variable region $(\mathrm{IgVH})$ mutation status $\mathrm{s}^{4,5}, 70 \mathrm{kDa}$ zeta-associated protein (ZAP70) expression ${ }^{6,7}$, and cytogenetic changes ${ }^{8}$.

MicroRNAs (miRNAs) are a large group of short non-coding single-stranded RNA molecules that affect numerous significant processes in cells by acting at the post-transcriptional level ${ }^{9,10}$. The process of miRNA biogenesis begins with the transcription of long precursors that are subsequently processed, giving rise to mature functional miRNA molecules that are 18 to 25 nucleotides long. These mature miRNA molecules are incorporated into the RNA-induced silencing complex (RISC) $\left(\right.$ ref. $\left.{ }^{11}\right)$. The mechanism of miRNA action is based on the modulation of gene expression at the post-transcriptional level by RNA interference, during which the translation of target mRNA is inhibited ${ }^{12}$. A single miRNA may regulate the expression of tens to hundreds of genes by the direct recognition of target mRNA based on complementarity with the three-prime untranslated region (3' UTR) of approximately 7 nucleotides of this target mRNA (ref. ${ }^{13}$ ), with the complementarity not necessarily reaching 100 percent. In silico predictive models suggest that miRNAs are responsible for the regulation of more than $30 \%$ of the human genome ${ }^{14}$.

In 2002, Calin et al ${ }^{15}$ discovered two miRNA genes that played a role in CLL pathogenesis, $m i R-15 a$ and $m i R$ 16-1. Both are located in the 13q14.3 region between two exons of the $D L E U 2$ gene. In patients diagnosed with 
CLL, 13q14 deletion is the most frequent chromosomal abnormality, and it is observed in more than half of cases. Although deletion of the $13 \mathrm{q} 14$ region is mostly monoallelic ( $\sim 76 \%$ of CLL cases), it is also detected in the biallelic form ( $\sim 24 \%$ of CLL cases) (ref. ${ }^{8,16}$ ).

The target gene for $m i R-15 a$ and $m i R-16-1$ is BCL2, as identified by Cimmino et al. ${ }^{17}$. Using heterologous cell lines, these authors confirmed that the expression of $m i R-15 a$ and $m i R-16-1$ in CLL is inversely correlated with expression of the BCL2 gene and that these miRNAs negatively regulate $B C L 2$ expression at the post-transcriptional level. The inactivation of $m i R-15 a$ and $m i R-16-1$ expression and subsequent increased expression of the $B C L 2$ gene contribute to CLL pathogenesis. However, this theory was refuted by some later studies ${ }^{18-20}$, which showed that the expansion of $\mathrm{B}$ cells is primarily controlled by the modulation of proliferation rather than influencing cell survival through the regulation of BCL2 expression. Another model suggests that the miR-16 family triggers the accumulation of cells in the G0/G1 phase through simultaneously silencing multiple genes of the cell cycle ${ }^{21}$.

This study aimed at determining the relative levels of $m i R-15 a$ and $m i R-16-1$ expression in a group of CLL patients with deletion of the $13 \mathrm{q} 14$ region detected by FISH and second, at assessing potential changes in $m i R$ $15 a$ and miR-16-1 expression with respect to the type of 13 q14 deletion present and other prognostically significant parameters.

\section{PATIENTS AND METHODS}

The group comprised 39 patients diagnosed with CLL in the Department of Hemato-Oncology of the University Hospital Olomouc. There were 29 men and 10 women (median age, 58.9 years; range, 34-74 years). Of these, 12 patients were examined at the time of diagnosis, 8 in the phase of stable disease and 16 during disease progression. In one patient, two biological samples were collected: one at the time of diagnosis (CLL12) and the other at the time of progression (CLL12*). Treatment was initiated in 32 patients with a median survival of 28.9 months. Median survival was assessed from overall survival, defined as the time from first treatment to the date of last follow-up examination or the date of death from any cause.

Following patients' informed consent, samples were taken as part of routine diagnostic procedures and used anonymously for research purposes with approval from the University Hospital ethics committee.

The patient cohort and clinical parameters are characterized in Table 1.

\section{Fluorescence in situ hybridization (FISH)}

All patients from the cohort were examined using a routine CLL FISH panel involving probes for detecting deletions of chromosomes 13q, 11q and 17p and trisomy of chromosome 12. Deletion of the $13 \mathrm{q} 14$ region was detected by FISH using the LSI D13S319 locus-specific probe (Abbott Molecular, IL, USA) of $\sim 130 \mathrm{~kb}$ contain- ing the 13 q 14.3 region. In each patient, at least 300 interphase nuclei were analyzed, and the results were assessed according to the ISCN 2009 (ref. ${ }^{22}$ ).

\section{Quantitative RT-PCR \\ RNA isolation}

The starting biological material for verification of miRNA expression was RNA obtained from the peripheral blood of patients diagnosed with CLL. Mononuclear cells were isolated by separation with Histopaque $\AA-1077$ density gradient medium (Sigma Aldrich, St. Louis, USA). Total cellular RNA was isolated with TRIzol@ reagent (Life Technologies, Carlsbad, USA) according to the manufacturer's instructions.

\section{Reverse transcription (RT)}

Complementary DNA (cDNA) for measuring the expression of $m i R-15 a$ and $m i R-16-1$ was obtained from 20 ng of total RNA. Reverse transcription was performed according to the manufacturer's instructions using the TaqMan ${ }^{\circledR}$ MicroRNA Reverse Transcription Kit (Life Technologies) and specific stem-loop RT primers contained in TaqMan ${ }^{\circledR}$ MicroRNA Assays (Life Technologies).

\section{qRT-PCR}

The expression of $m i R-15 a$ and $m i R-16-1$ was determined with a quantitative system based on TaqMan ${ }^{\circledR}$ probe technology (Life Technologies). The assay was performed in a total reaction volume of $20 \mu \mathrm{L}$ and contained $7.67 \mu \mathrm{L}$ of nuclease-free water, $10 \mu \mathrm{L}$ of TaqMan ${ }^{\circledR}$ Universal PCR Master Mix, No AmpErase ${ }^{\circledR}$ UNG (Life Technologies), $1 \mu \mathrm{L}$ of a TaqMan ${ }^{\circledR}$ MicroRNA Assays specific primer (Life Technologies), and $1.33 \mu \mathrm{L}$ of cDNA generated by reverse transcription. The expression of $m i R$ $15 a$ and $m i R-16-1$ was measured with a LightCycler ${ }^{\circledR} 480$ Real-Time PCR System (Roche, Basel, Switzerland) under the following conditions: $95^{\circ} \mathrm{C}$ for $10 \mathrm{~min}, 40$ cycles 95 ${ }^{\circ} \mathrm{C}$ for $15 \mathrm{~s}$ and $60{ }^{\circ} \mathrm{C}$ for $1 \mathrm{~min}$, and $40{ }^{\circ} \mathrm{C}$ for $1 \mathrm{~h}$. In a single experiment, each patient's sample was measured three times for the calculation of a normalized expression value (see below).

miRNA expression assay

The relative expression of $m i R-15 a$ and $m i R-16-1$ was determined by the $\Delta \Delta \mathrm{Ct}$ method $^{23}$. The reference (housekeeping) gene was small nuclear RNA (snRNA) U6 (RNU6B). As a calibrator, a mixed sample of blood collected from 10 healthy donors was used. Normalized $m i R$ $15 a$ and $m i R-16-1$ expression values for individual patients were calculated as follows: $\Delta \mathrm{Ct}=\mathrm{Ct}$ (target miRNA) $-\mathrm{Ct}$ (RNU6B); $\Delta \Delta \mathrm{Ct}=\Delta \mathrm{Ct}$ (patient) $-\Delta \mathrm{Ct}$ (calibrator); and normalized expression value $=2^{-\Delta \Delta \mathrm{Ct}}$. The final normalized $m i R-15 a$ and $m i R-16-1$ expression values for individual patients were expressed as the mean values calculated from three technical repeats (MS Excel 2007, Microsoft, Redmond, USA). 
Table 1. Clinical data and parameters of the patient cohort.

\begin{tabular}{|c|c|c|c|c|c|c|c|c|}
\hline Case & Gender $^{1}$ & $\begin{array}{c}\text { Age at } \\
\text { diagnosis }\end{array}$ & Binet stage & Survival $^{3}$ & $\begin{array}{l}\text { Clinical } \\
\text { phase }^{4}\end{array}$ & $\begin{array}{c}\text { Percentage of } \\
\text { pathological } \\
\text { clones }^{5}\end{array}$ & ZAP- $70^{6}$ & $\begin{array}{c}\text { Mutation } \\
\text { status of } \\
\mathrm{IgVH}^{7}\end{array}$ \\
\hline CLL1 & $\mathrm{M}$ & 34.6 & $\mathrm{C}$ & 37.1 & DG & $90 \%$ & $\mathrm{P}$ & UM \\
\hline CLL2 & M & 71.6 & A & 51.5 & SD & $80 \%$ & $\mathrm{~N}$ & $\mathrm{M}$ \\
\hline CLL3 & M & 73.3 & B & 18.6 & PD & $90 \%$ & $\mathrm{P}$ & UM \\
\hline CLL4 & M & 50.9 & B & 49.1 & SD & $70 \%$ & $P$ & M \\
\hline CLL5 & $\mathrm{F}$ & 61.0 & B & 70.6 & PD & $45 \%$ & $\mathrm{P}$ & M \\
\hline CLL6 & M & 46.3 & B & 25.0 & PD & $70 \%$ & $\mathrm{P}$ & UM \\
\hline CLL7 & M & 70.1 & A & 54.8 & SD & $70 \%$ & $\mathrm{~N}$ & UM \\
\hline CLL8 & M & 60.8 & $\mathrm{C}$ & 29.0 & DG & $70 \%$ & $\mathrm{P}$ & UM \\
\hline CLL9 & M & 70.3 & $\mathrm{C}$ & 28.9 & PD & $80 \%$ & $\mathrm{n} / \mathrm{a}$ & UM \\
\hline CLL10 & $\mathrm{F}$ & 41.0 & A & 115.7 & SD & $90 \%$ & $\mathrm{~N}$ & $\mathrm{M}$ \\
\hline CLL11 & M & 56.7 & $\mathrm{C}$ & 143.1 & PD & $90 \%$ & $\mathrm{P}$ & UM \\
\hline CLL12 & M & 49.5 & A & 69.1 & DG & $60 \%$ & $\mathrm{n} / \mathrm{a}$ & UM \\
\hline CLL12* & M & 49.5 & A & 69.1 & PD & $60 \%$ & $\mathrm{n} / \mathrm{a}$ & UM \\
\hline CLL13 & M & 57.2 & A & 50.8 & DG & $60 \%$ & $\mathrm{P}$ & $\mathrm{M}$ \\
\hline CLL14 & M & 55.9 & B & 90.1 & PD & $90 \%$ & $\mathrm{P}$ & $\mathrm{UM} / \mathrm{M}$ \\
\hline CLL15 & M & 58.6 & A & 12.8 & SD & $60 \%$ & $\mathrm{~N}$ & UM \\
\hline CLL16 & $\mathrm{F}$ & 63.2 & B & 21.6 & PD & $80 \%$ & $\mathrm{P}$ & UM \\
\hline CLL17 & $\mathrm{F}$ & 56.7 & $\mathrm{C}$ & 77.2 & PD & $70 \%$ & $\mathrm{P}$ & UM \\
\hline CLL18 & M & 52.4 & B & 20.7 & SD & $90 \%$ & $\mathrm{P}$ & UM \\
\hline CLL19 & M & 68.5 & B & 16.7 & PD & $90 \%$ & $\mathrm{n} / \mathrm{a}$ & UM \\
\hline CLL20 & M & 59.3 & $\mathrm{C}$ & 68.1 & PD & $\mathrm{n} / \mathrm{a}$ & $\mathrm{n} / \mathrm{a}$ & UM \\
\hline CLL21 & M & 58.3 & B & 26.6 & PD & $90 \%$ & $\mathrm{P}$ & UM \\
\hline CLL22 & $\mathrm{F}$ & 51.9 & B & 201.0 & SD & $80 \%$ & $\mathrm{P}$ & $\mathrm{M}$ \\
\hline CLL23 & M & 63.2 & $\mathrm{C}$ & 96.3 & PD & $\mathrm{n} / \mathrm{a}$ & $\mathrm{n} / \mathrm{a}$ & M \\
\hline CLL24 & M & 73.8 & A & 25.1 & SD & $40 \%$ & $\mathrm{P}$ & $\mathrm{M}$ \\
\hline CLL25 & M & 59.9 & $\mathrm{C}$ & 79.8 & PD & $70 \%$ & $\mathrm{P}$ & $\mathrm{UM}$ \\
\hline CLL26 & $\mathrm{F}$ & 58.9 & $\mathrm{C}$ & 89.6 & PD & $80 \%$ & $\mathrm{P}$ & $\mathrm{UM} / \mathrm{M}$ \\
\hline CLL27 & M & 74.0 & A & 24.6 & SD & $60 \%$ & $\mathrm{P}$ & UM \\
\hline CLL28 & M & 60.6 & A & 12.0 & DG & $60 \%$ & $\mathrm{~N}$ & UM \\
\hline CLL29 & M & 46.4 & B & 11.1 & DG & $70 \%$ & $\mathrm{~N}$ & UM \\
\hline CLL30 & M & 43.6 & B & 54.6 & PD & $70 \%$ & $\mathrm{~N}$ & UM \\
\hline CLL31 & M & 49.3 & A & 23.6 & DG & $85 \%$ & $\mathrm{P}$ & UM \\
\hline CLL32 & M & 65.2 & $\mathrm{C}$ & 17.0 & PD & $70 \%$ & $\mathrm{~N}$ & UM \\
\hline CLL33 & M & 58.8 & $\mathrm{C}$ & 22.1 & DG & $73 \%$ & $\mathrm{P}$ & UM \\
\hline CLL34 & $\mathrm{F}$ & 71.0 & A & 21.7 & DG & $60 \%$ & $\mathrm{~N}$ & UM \\
\hline CLL35 & $\mathrm{F}$ & 69.3 & $\mathrm{C}$ & 88.2 & PD & $80 \%$ & $\mathrm{n} / \mathrm{a}$ & $\mathrm{M}$ \\
\hline CLL36 & M & 52.4 & A & 23.4 & DG & $75 \%$ & $\mathrm{P}$ & UM \\
\hline CLL37 & M & 66.5 & A & 24.1 & DG & $50 \%$ & $\mathrm{n} / \mathrm{a}$ & UM \\
\hline CLL38 & $\mathrm{F}$ & 61.6 & A & 21.7 & DG & $80 \%$ & $\mathrm{P}$ & $\mathrm{M}$ \\
\hline CLL39 & $\mathrm{F}$ & 50.0 & $\mathrm{~B}$ & 24.0 & DG & $50 \%$ & $\mathrm{P}$ & UM \\
\hline
\end{tabular}

Footnotes: ${ }^{1}$ gender; $\mathrm{M}=$ male, $\mathrm{F}=$ female

${ }^{2}$ patients age at the time of diagnosis in years

${ }^{3}$ overall survival in months

${ }^{4}$ phase of clinical examination in which the analysis was performed; DG = time of diagnosis,

$\mathrm{SD}=$ stable disease, $\mathrm{PD}=$ disease progression

${ }^{5}$ percentage of pathological clone CD5+/CD19+/CD23+, n/a - not available

${ }^{6} \mathrm{ZAP}-70 ; \mathrm{P}=$ positive, $\mathrm{N}$ = negativ, $\mathrm{n} / \mathrm{a}-$ not available

${ }^{7}$ mutation status of $\mathrm{IgVH} ; \mathrm{M}=$ mutated, $\mathrm{UM}=$ unmutated, $\mathrm{UM} / \mathrm{M}=$ intermediate homology 


\section{Statistical analysis}

Statistical analyses were carried out with the SPSS v. 15 software (SPSS Inc., Chicago, USA). Fisher's exact test was used to analyze categorical parameters. Quantitative parameters were analyzed using the following non-parametric methods: the Mann-Whitney U test, the Kruskal-Wallis ANOVA and Spearman's rank correlation analysis. The Shapiro-Wilk test was used to test the normal distribution of analyzed data. The statistical analyses were performed at a $5 \%$ significance level.

\section{RESULTS}

\section{FISH}

Of a total of 39 CLL patients, deletion of the 13q14 region was found in 31 patients (32 biological samples) (Table 2). In this group, 13q14 deletion as a single aberration was observed in 11 patients, with ATM deletion in 12 patients, with TP53 deletion in 5 patients, and with trisomy 12 in one patient; three patients had a complex karyotype. The group of 8 controls with CLL comprised 2 patients with a normal karyotype and positive FISH findings, two patients with ATM deletion, one patient with TP53 deletion, two patients with trisomy 12, and one patient with $6 \mathrm{q}$ deletion.

In 20 out of $32(62.5 \%)$ biological samples, only monoallelic 13q14 deletion was observed. In 8 (25\%) samples, both monoallelic and biallelic $13 \mathrm{q} 14$ deletion were observed. In the remaining 4 (12.5\%) samples, only biallelic deletion was noted (Table 2 ). In one case, two biological samples (CLL12 and CLL12*) were collected from a single patient. In the sample collected at the time of diagnosis, monoallelic 13q14 deletion was observed in 93\% of cells (Fig.1A), whereas biallelic 13q14 deletion was observed in $93 \%$ of cells in the sample taken during the disease progression (Fig.1B). The group of 8 patients without $13 \mathrm{q} 14$ deletion served as controls for measuring the expression of miR-15a and miR-16-1.

\section{qRT-PCR - CLL patients}

Quantitative RT-PCR was used to determine the levels of $m i R-15 a$ and $m i R-16-1$ expression in the group of 39 patients diagnosed with CLL (Table 2).

The values of miRNA expression were related to the following patient individual clinical parameters: sex, age at diagnosis, clinical stage of the disease according to Binet's system, overall survival, expansion of the pathological clone, presence of the ZAP-70 marker, and IgVH mutation status. Statistical analysis revealed a moderate negative correlation between normalized miR-15a expression values and patient age at diagnosis and a weak negative correlation between normalized miR-16-1 expression values and patient age at diagnosis (data not shown). The other diagnostic parameters did not show a significant relationship with the levels of expression of either miRNA (unpublished results).

The levels of $m i R-15 a$ and $m i R-16-1$ expression were different among individual patients from the cohort, despite both miRNAs being colocalized in the $13 \mathrm{q} 14.3$ region. The control group of 8 patients without $13 \mathrm{q} 14$ deletion (as revealed by FISH) showed marked variability in the expression of $m i R-15 a$ and $m i R-16-1$ (Fig. 2 ). The normalized values of expression of both miRNAs ranged from 0.818 to 3.864 . A high variability in $m i R-15 a$ and $m i R-16-1$ expression was also observed in the group of patients with monoallelic 13q14 deletion (Fig. 3). Significantly higher normalized levels of $m i R-15 a$ expression were found in the controls and patients with monoallelic 13q14 deletion compared with patients with biallelic deletion $(P=0.045)$. There was no significant relationship between normalized levels of expression of the two miRNAs and monoallelic deletion of the $13 \mathrm{q} 14$ region. Similarly, no significant difference in normalized levels of $m i R-15 a$ and $m i R-16$ -
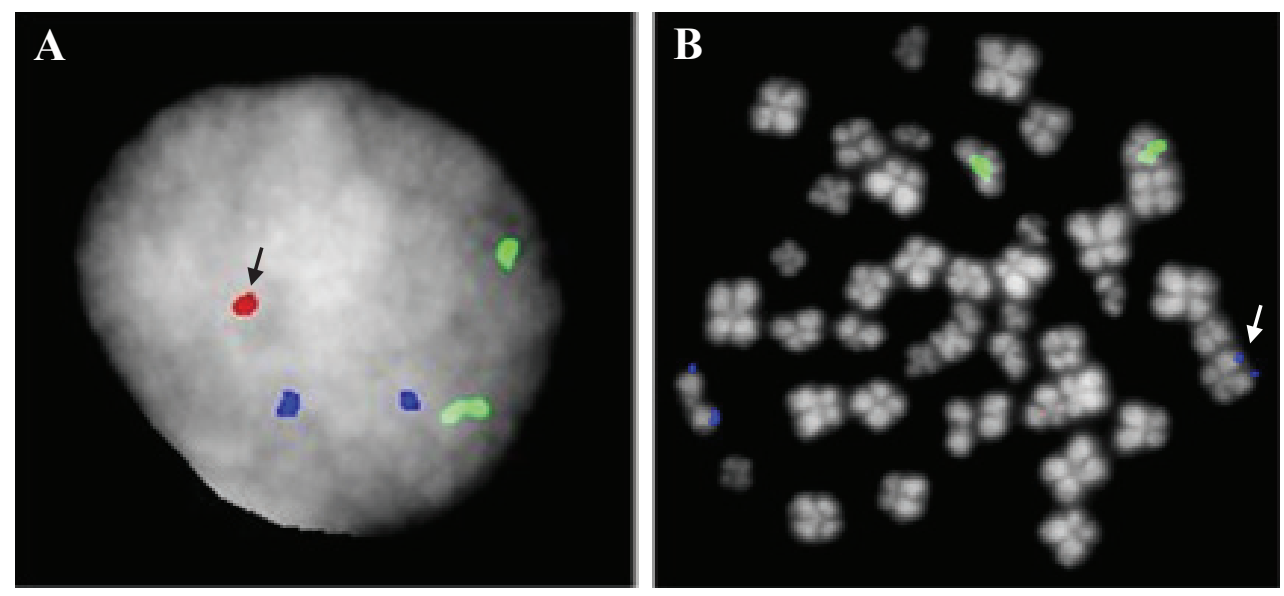

Fig. 1. Example of 13q14 deletion using FISH in Patient CLL12. A. Monoallelic 13q14 deletion at the time of diagnosis (CLL12); probe LSI D13S319 (red) /13q34 (blue)/ CEP12 (green) (see Material and Methods). Monoallelic 13q14 deletion was observed in an interphase cell (single red signal marked by an arrow). B. Biallelic 13q14 deletion (red signal is missing) was observed in metaphase chromosomes in disease progression (CLL12*). Region 13q34 was translocated onto another chromosome (marked by an arrow). 
Table 2. Results of qRT-PCR, FISH and conventional cytogenetic examination.

\begin{tabular}{|c|c|c|c|c|c|c|c|c|}
\hline \multirow{2}{*}{ Case } & \multirow{2}{*}{$m i R-15 a^{1}$} & \multirow{2}{*}{$\operatorname{miR}-16-1^{2}$} & \multicolumn{2}{|c|}{ Deletion of $13 \mathrm{q} 14^{3}$} & \multirow{2}{*}{$11 q^{-}{ }^{4}$} & \multirow{2}{*}{$17 p-{ }^{5}$} & \multirow{2}{*}{$+12^{6}$} & \multirow{2}{*}{$\begin{array}{l}\text { Conventional } \\
\text { cytogenetics }\end{array}$} \\
\hline & & & monoallelic & biallelic & & & & \\
\hline CLL1 & 1.165 & 1.347 & $97 \%$ & & $96 \%$ & & & UNS \\
\hline CLL2 & 0.895 & 1.301 & $64 \%$ & $28 \%$ & & & & NK \\
\hline CLL3 & 2.346 & 2.297 & $93 \%$ & & & $93 \%$ & & NK \\
\hline CLL4 & 1.021 & 0.432 & $75 \%$ & $6 \%$ & & & & UNS \\
\hline CLL5 & 0.196 & 0.582 & & $96 \%$ & $13 \%$ & & & CK \\
\hline CLL6 & 1.932 & 0.742 & $86 \%$ & & $88 \%$ & & & UNS \\
\hline CLL7 & 0.163 & 0.570 & & $96 \%$ & $25 \%$ & & & UNS \\
\hline CLL8 & 1.741 & 0.933 & $81 \%$ & $7 \%$ & $88 \%$ & & & CK \\
\hline CLL9 & 0.551 & 1.262 & $91 \%$ & & $94 \%$ & & & UNS \\
\hline CLL10 & 1.537 & 2.657 & $91 \%$ & $3 \%$ & & & & NK \\
\hline CLL11 & 0.790 & 1.042 & $96 \%$ & & $95 \%$ & & & NK \\
\hline CLL12 & 1.102 & 1.346 & $93 \%$ & & & $93 \%$ & & UNS \\
\hline CLL12* & 0.227 & 0.218 & & $93 \%$ & & $95 \%$ & & CK \\
\hline CLL13 & 2.868 & 3.837 & $48 \%$ & & & & & NK \\
\hline CLL14 & 2.990 & 1.602 & $63 \%$ & $35 \%$ & $85 \%$ & & & CK \\
\hline CLL15 & 4.056 & 3.630 & $76 \%$ & & $91 \%$ & & & $\mathrm{CCH}$ \\
\hline CLL16 & 0.979 & 0.758 & $87 \%$ & & & $97 \%$ & & $N D$ \\
\hline CLL17 & 2.433 & 2.056 & $69 \%$ & & & & & NK \\
\hline CLL18 & 1.580 & 1.729 & $77 \%$ & $17 \%$ & $47 \%$ & & & NK \\
\hline CLL19 & 1.682 & 1.815 & $97 \%$ & & & $55 \%$ & & UNS \\
\hline CLL20 & 0.117 & 0.297 & $4 \%$ & $77 \%$ & $60 \%$ & & & $\mathrm{CCH}$ \\
\hline CLL21 & 1.591 & 5.657 & $88 \%$ & & & & & NK \\
\hline CLL22 & 0.908 & 1.014 & $30 \%$ & $62 \%$ & & & & $\mathrm{CCH}$ \\
\hline CLL23 & 0.559 & 1.197 & $92 \%$ & & & & & CK \\
\hline CLL24 & 1.125 & 1.214 & $43 \%$ & & & & $43 \%$ & NK \\
\hline CLL25 & 3.784 & 0.395 & $84 \%$ & & & & & CK \\
\hline CLL26 & 0.129 & 0.395 & & $95 \%$ & & & & CK \\
\hline CLL27 & 0.758 & 1.753 & $66 \%$ & & & & & NK \\
\hline CLL28 & 1.945 & 3.010 & $82 \%$ & & & & & NK \\
\hline CLL29 & 2.828 & 2.129 & $81 \%$ & & & & & $\mathrm{CCH}$ \\
\hline CLL30 & 4.659 & 3.227 & $39 \%$ & & & & & UNS \\
\hline CLL31 & 4.891 & 3.706 & $53 \%$ & & $92 \%$ & & & UNS \\
\hline CLL32 & 3.249 & 3.095 & & & & & & NK \\
\hline CLL33 & 0.818 & 2.603 & & & & $85 \%$ & & CK \\
\hline CLL34 & 0.920 & 1.625 & & & $90 \%$ & & & $\mathrm{CCH}$ \\
\hline CLL35 & 1.042 & 1.474 & & & & & $79 \%$ & $\mathrm{CCH}$ \\
\hline CLL36 & 2.378 & 3.864 & & & $78 \%$ & & & UNS \\
\hline CLL37 & 0.835 & 2.549 & & & & & $73 \%$ & $\mathrm{CCH}$ \\
\hline CLL38 & 1.189 & 2.071 & & & & & & UNS \\
\hline CLL39 & 1.165 & 1.705 & & & & & & $\mathrm{CCH}$ \\
\hline
\end{tabular}

Footnotes: ${ }^{1}$ normalized values of $m i R-15 a$ expression

${ }^{2}$ normalized values of $m i R$-16-lexpression

${ }^{3}$ detection of 13q14 deletion using FISH (probe LSI D13S319/13q34/CEP12)

${ }^{4}$ detection of $11 \mathrm{q}$ deletion using FISH (LSI ATM probe )

${ }^{5}$ detection of $17 \mathrm{p}$ deletion using FISH (LSI p53 probe)

${ }^{6}$ detection of trisomy of chromosome 12 using FISH (CEP 12 probe)

${ }^{7}$ the karyotype examination using conventional cytogenetics

$$
\begin{aligned}
& \text { UNS - unsuccessful } \\
& \text { NK - normal karyotype } \\
& \text { CCH - chromosomal changes } \\
& \text { CK - complex karyotype }
\end{aligned}
$$




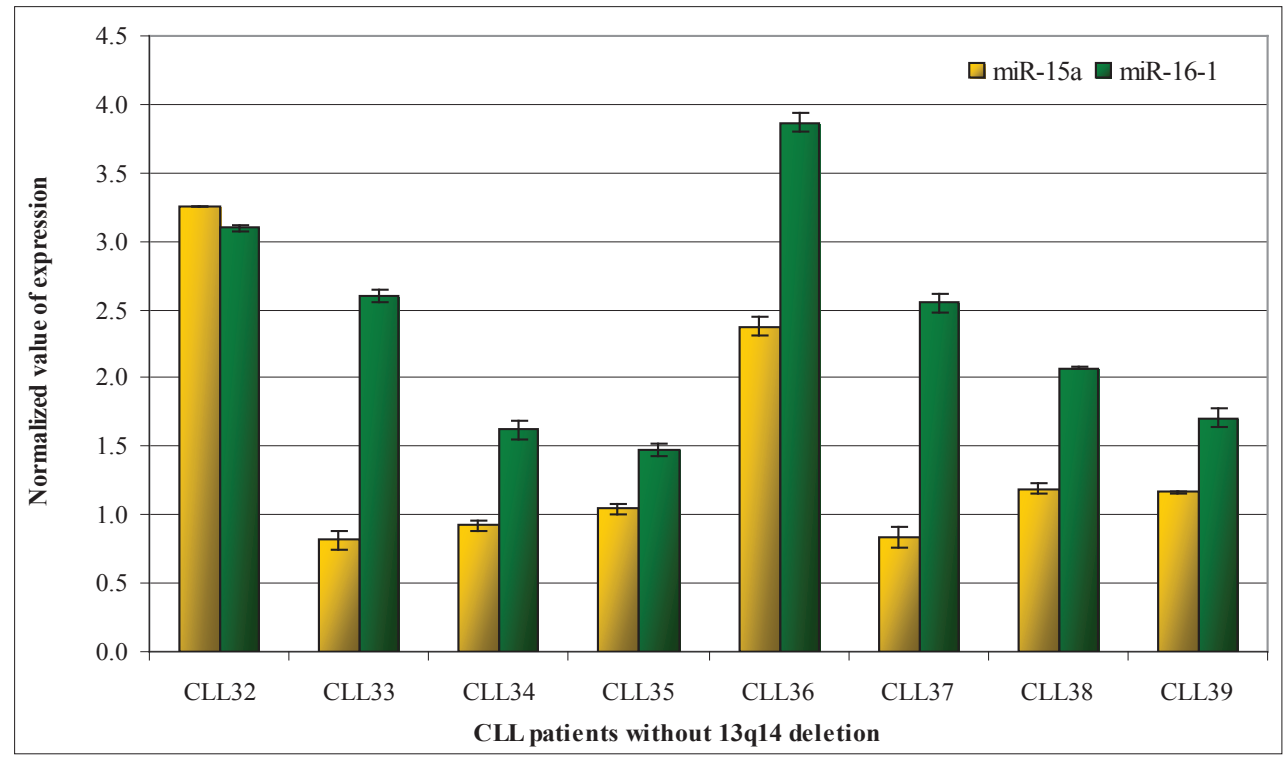

Fig.2. Expression of miR-15a (yellow) and miR-16-1 (green) in a group of patients without 13q14 deletion (control group).

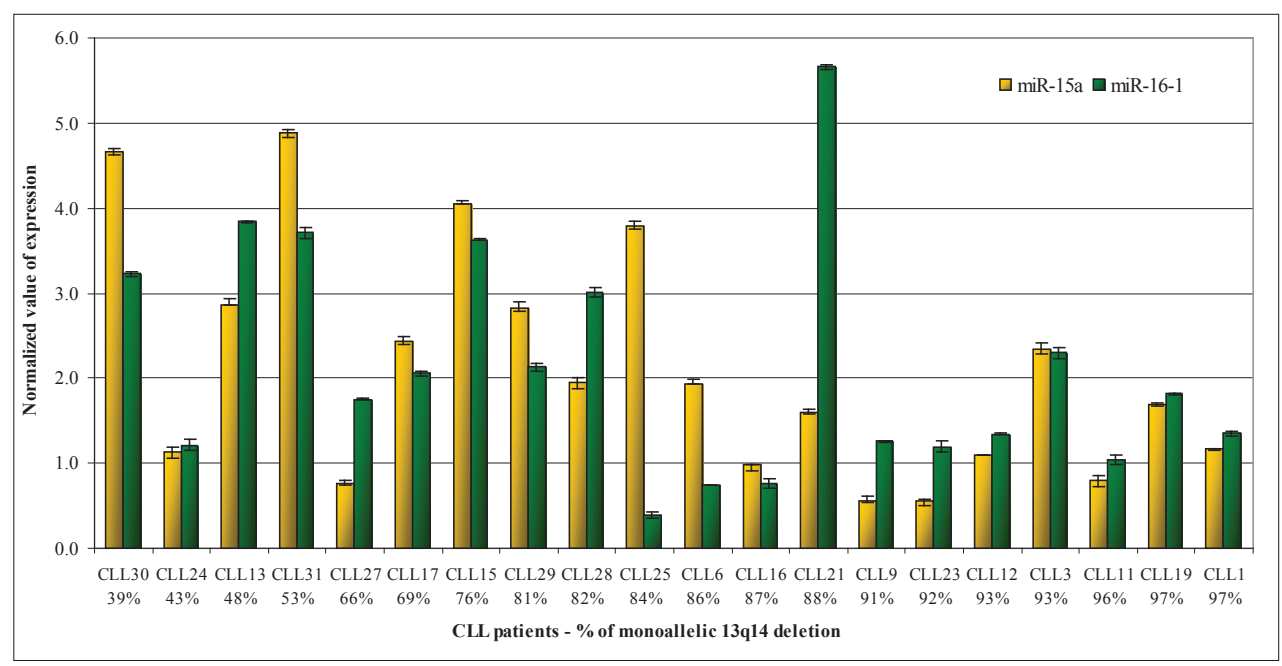

Fig. 3. Expression of $m i R-15 a$ (yellow) and $m i R-16-1$ (green) in a group of patients with monoallelic 13q14 deletion.

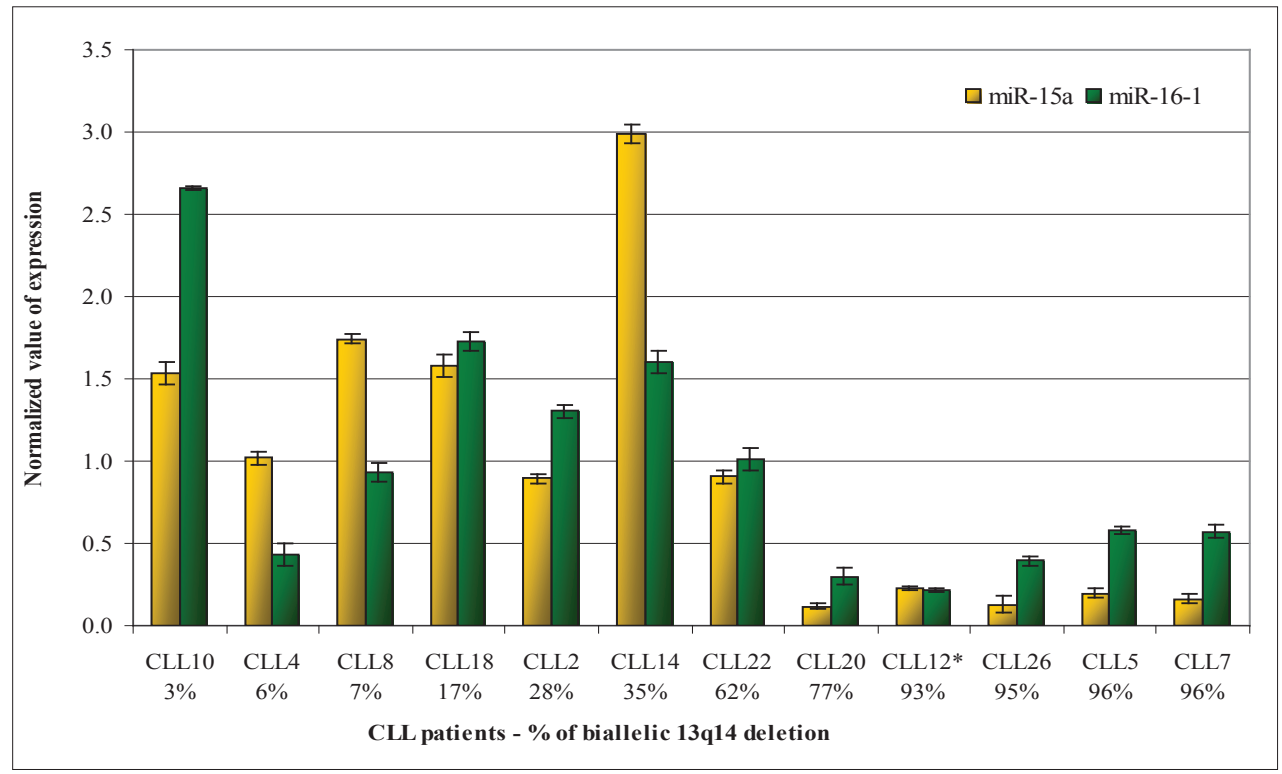

Fig. 4. Expression of miR-15a (yellow) and miR-16-1 (green) in a group of patients with biallelic 13q14 deletion. 


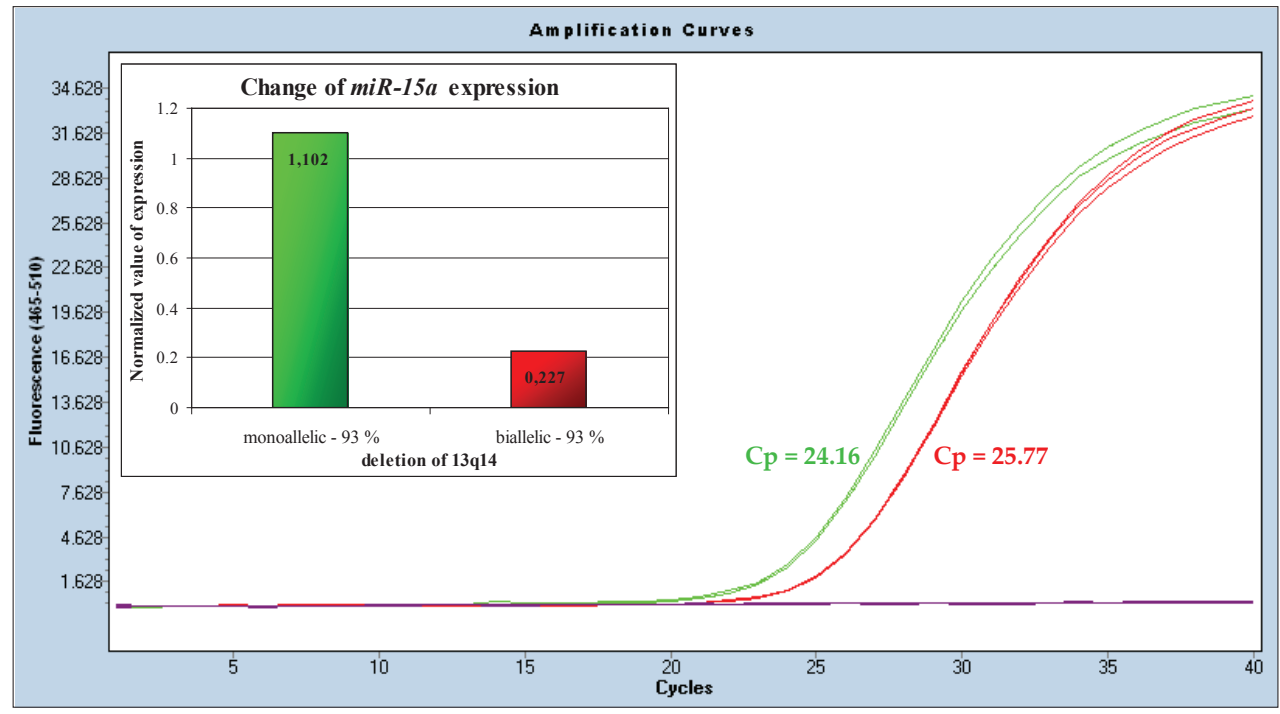

Fig. 5. Change of miR-15a expression in Patient CLL12.Amplification curves and Cp values at the time of diagnosis (green) and in disease progression (red). The bar chart shows miR-15a transcript content and its dependence on the type of $13 \mathrm{q} 14$ deletion at the time of diagnosis (green) and in disease progression.

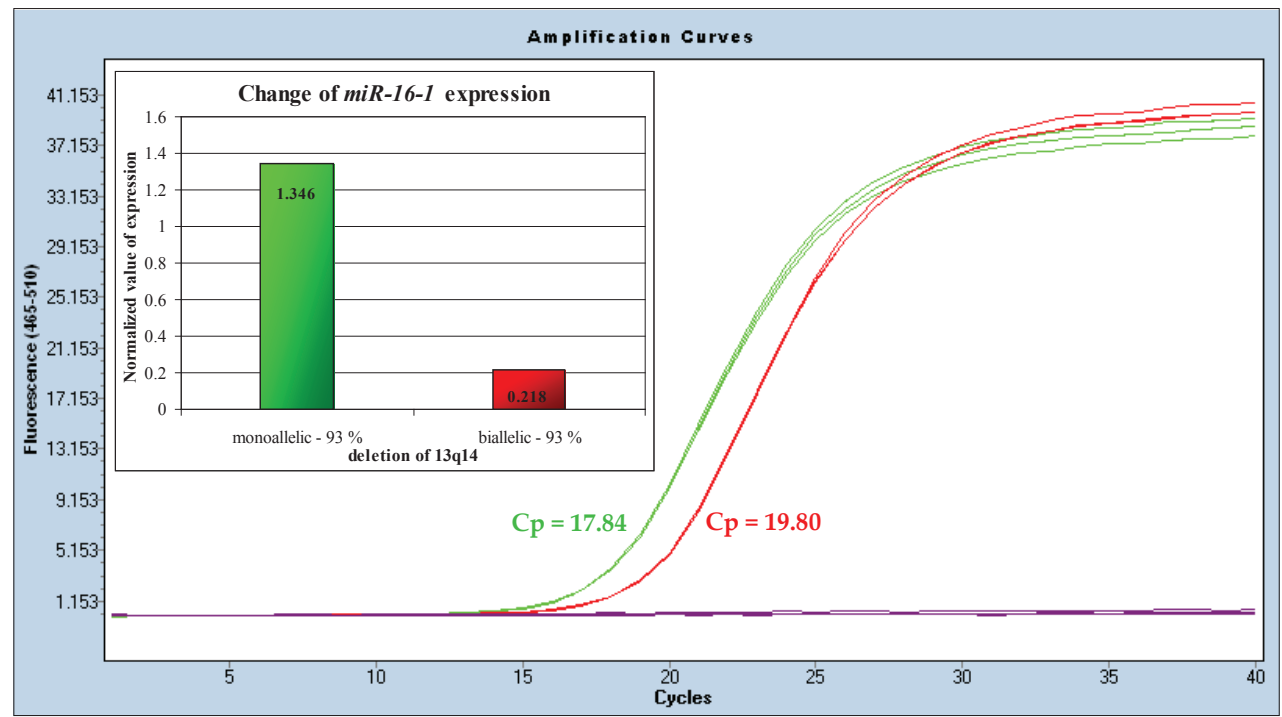

Fig. 6. Change of miR-16-1 expression in Patient CLL12. Amplification curves and Cp values at the time of diagnosis (green) and in disease progression (red). The bar chart shows miR-16-1 transcript content and its dependence on the type of 13q14 deletion at the time of diagnosis (green) and in disease progression.

1 expression was found between patients without $13 \mathrm{q} 14$ deletion and those with monoallelic 13q14 deletion.

In patients with biallelic 13q14 deletion, there was a significant decrease in $m i R-15 a$ and $m i R-16-1$ expression in individuals in whom FISH revealed biallelic deletion in at least $77 \%$ of cells (Fig. 4 ). There was a weak negative correlation between normalized levels of miR-16-1 expression and biallelic deletion of the 13q14 region (unpublished results).

\section{qRT-PCR - Patient CLL12}

In Patient CLL12 (male, aged 50 years at the time of diagnosis), the levels of $m i R-15 a$ and $m i R-16-1$ expression were determined in two biological samples taken at the time of diagnosis and during progression of the disease. At the time of diagnosis, FISH revealed monoallelic 13q14 deletion in $93 \%$ of the patient's cells (CLL12). Over 67 months, the patient's disease progressed, and FISH confirmed the presence of biallelic 13q14 deletion in $93 \%$ of cells (CLL12*). Using qRT-PCR, the levels of $m i R-15 a$ and $m i R-16-1$ expression were determined.

In the sample obtained at diagnosis (93\% of cells with monoallelic 13q14 deletion), the normalized values of miR-15a and miR-16-1 expression were 1.102 and 1.346 , respectively. In the progression sample (93\% of cells with biallelic 13q14 deletion), the expression of both miRNAs was significantly decreased. For $m i R-15 a$, the level of expression was 4.85 -fold lower compared with 
the sample taken at diagnosis (normalized value of $m i R$ $15 a$ expression $=0.227$ ) $($ Fig. 5). For $m i R-16-1,6.17$-fold lower expression was observed compared with the sample obtained at diagnosis (normalized value of $m i R-16-1$ expression $=0.218)($ Fig. 6) .

\section{DISCUSSION}

The deletion of chromosome $13 \mathrm{q} 14$ is the most frequent chromosomal aberration found in patients with CLL. FISH is a routine method for its identification, which is of prognostic significance. CLL patients with a normal karyotype or with $13 q 14$ deletion as the only genetic abnormality have a better prognosis than CLL patients with complex karyotypes or deletions of the 11q23 or $17 \mathrm{p} 13$ regions $^{8,24-26}$. Isolated deletion of the $13 \mathrm{q} 14$ region is associated with a lower level of expression of ZAP70 and the $\mathrm{IgVH}$ gene mutation status ${ }^{24}$. Although $13 q 14$ deletion is considered to be associated with a favorable prognosis, some studies have shown that this is not true for some patients. It has been confirmed that heterogeneity of the $13 \mathrm{q} 14$ deleted region and the presence of biallelic deletion may significantly contribute to the course of the disease ${ }^{19}$. In our cohort, deletion of this region was detected in 31 patients ( 32 biological samples). One patient (CLL12) was investigated both at the time of diagnosis and during disease progression. Monoallelic 13q14 deletion was found in $62.5 \%$ of 32 biological samples and with biallelic $13 \mathrm{q} 14$ deletion in $25 \%$ of cases. In $12.5 \%$ of 32 biological samples, biallelic 13q14 deletion was found. As $13 q 14$ deletion is not present in all CLL patients, it is obvious that this abnormality is not primarily responsible for the development of the condition; however, its significance as a prognostic factor has been confirmed ${ }^{8,24}$. According to Oscier et al. ${ }^{25}$, deletion of the $13 \mathrm{q} 14$ region is associated with the IgVH gene mutation status. In our group, however, there was no significant association between $\mathrm{IgVH}$ gene mutation status and $13 \mathrm{q} 14$ deletion. Deletion of the $13 \mathrm{q} 14$ region was not the only genetic abnormality. In most patients, deletion was observed with other changes (11q-, 17p-, +12 and others). However, the identified aberrations were not directly associated with the presence, type or frequency of 13q14 deletion.

This study aimed at determining the levels of expression of $m i R-15 a$ and $m i R-16-1$ in a group of CLL patients divided into three subgroups: patients without deletion, patients with monoallelic deletion and patients with biallelic deletion of the $13 \mathrm{q} 14$ region. The expression of miRNAs was normalized to healthy controls. The levels of $m i R-15 a$ and $m i R-16-1$ expression were different in individual patients, despite both miRNAs being colocalized in the $13 \mathrm{q} 14.3$ region. This result is suggestive of the different regulation of expression of both miRNAs and is likely to be indicative of their functional independence.

Variable expression was also observed in both patients without $13 q 14$ deletion and the group of patients with monoallelic 13q14 expression. No significant decrease in expression was observed in either of the studied miRNAs depending on the percentage of cells with monoallelic $13 q 14$ deletion. As recently reported, the decreased expression of $m i R-15 a$ and $m i R-16-1$ in cases without $13 q 14$ deletion may also result from epigenetic changes. Sampath et al. ${ }^{27}$ found that the genes for $m i R-15 a$ and $m i R-16-1$ are silenced through histone deacetylases that are highly expressed in CLL. Moreover, the extent of potential deletion of the $13 \mathrm{q} 14$ region, where $m i R-15 a$ and $m i R-16-1$ are located, can be variable ${ }^{19}$, and this may affect the heterogeneous profile of expression of both miRNAs. It was also observed that the variability in expression may be due to the presence of homologous gene loci $\mathrm{miR}-15 \mathrm{~b} / \mathrm{miR}-16-2$ in the $3 q 25-26.1$ region and $m i R-497 / m i R-195$ in the $17 \mathrm{q} 21$ region. Given their high sequence homology, $m i R-15 a$ and $m i R-16-1$ may not be distinguishable from redundant miRNAs using qRT-PCR primers. This may significantly influence the results of analyses ${ }^{28-30}$. It is also likely that if there is at least one functional allele in a cell, this allele will substitute for the other non-functional deleted allele by increasing its expression. Thus, no significant decrease in the levels of $m i R-15 a$ and miR-16-1 would be observed.

In the group of patients with biallelic 13q14 deletion, significant variability in the measured levels of $m i R-15 a$ and miR-16-1 expression was noted, with the exception of patients with biallelic deletion in $77 \%$ or more of the cells. These patients were found to have a significantly lower expression of both miRNAs. The relationship between levels of miR-15a and miR-16-1 expression and other clinical parameters studied in the whole group showed no statistical significance (unpublished results), which may be due to small sample size.

Investigations revealing the significance of miRNAs in tumorigenesis involved molecular biology studies of patients with CLL (ref. ${ }^{15,31,32}$ ). An analysis of an approximately $30-\mathrm{kb}$ minimal deleted region (MDR) in $13 \mathrm{q} 14$ led to the discovery of the $m i R-15 a$ and $m i R-16-1$ genes and the finding that these genes are deleted or down-regulated in $\sim 68 \%$ of CLL cases $^{15}$. In another study, a total of 13 miRNAs were selected, and their expression profiles enabled the stratification of CLL patients into prognostic groups. These miRNAs included $m i R-15 a$ and $m i R-16-1$ $\left(\right.$ ref. $^{33}$ ). It is generally assumed that approximately $50 \%$ of genes encoding miRNAs are located in regions that are frequently susceptible to breaks, deletions and mutations during tumorigenesis ${ }^{11,31}$. These regions include both oncogenes and tumor suppressors ${ }^{34}$, which thus play an important role in the initiation and progression of human tumors.

Earlier studies reported decreased expression of $m i R$ $15 a$ and $m i R-16-1$ in most CLL cases ${ }^{15,17,31-33}$. More recent studies, however, have not confirmed any a correlation between the levels of expression of these two miRNAs and the presence of $13 \mathrm{q} 14$ deletion ${ }^{19,35}$. Our study showed a significant decrease in expression of both miRNAs in a small group of patients (12.8\% of the entire cohort). These data correspond to the results of Fulci et al. ${ }^{18}$, who showed a markedly decreased expression of $m i R-15 a$ and miR-16-1 in patients diagnosed with CLL. Similar to our study, they observed biallelic $13 \mathrm{q} 14$ deletion in a high proportion of CLL cells ( $63 \%$ - $85 \%)$ of these patients. 
As mentioned above, the $13 \mathrm{q} 14$ region is deleted in patients $^{8}$. The location of miR-15a and miR-16-1 in this region suggests that the role of these miRNAs in the pathogenesis of CLL is not negligible ${ }^{15}$. Based on our own research, we assume that both miRNAs act as tumor suppressors, as confirmed by Patient CLL12 whose disease progression was associated with newly present biallelic $13 \mathrm{q} 14$ deletion and a related significant decrease in $\mathrm{miR}$ $15 a$ and $m i R-16-1$ expression.

At present, studies of the expression of selected miRNAs are a useful tool for determining the prognosis, prediction of treatment response and development of the disease in patients with lymphoproliferative disease ${ }^{36}$. Determining the levels of miRNA expression is beneficial for not only distinguishing healthy and malignant tissues but also the classification of tumor types and degree of disease progression. The deregulation of miRNA expression is likely to be one of the critical points in the pathogenesis of lymphoproliferative diseases. However, molecular mechanisms of regulation and functions of this group of RNA must be carefully analyzed. More detailed studies aimed at understanding the roles of selected miRNAs in the development and progression of diseases and the identification of new miRNA genes could lead to more accurate diagnoses, prognoses and therapeutic applications in the treatment of lymphoproliferative diseases.

\section{CONCLUSION}

This study aimed at determining the relative levels of $m i R-15 a$ and $m i R-16-1$ expression in a group of CLL patients with deletion of the 13q14 region detected by FISH and second, at assessing potential changes in $m i R$ $15 a$ and $m i R-16-1$ expression with respect to the type of 13q14 deletion present. The results showed different levels of miRNA expression in individual patients. Significantly higher normalized levels of $m i R-15 a$ expression were found in the control group and patients with monoallelic $13 q 14$ expression compared with patients with biallelic deletion. The significantly decreased expression of both miRNAs was detected in patients with biallelic deletion of the $13 \mathrm{q} 14$ region but only when deletions were present in $77 \%$ or more of cells, as detected by fluorescent in situ hybridization (FISH).

\section{ACKNOWLEDGEMENT}

We thank Jana Zapletalová (Department of Medical Biophysics, Faculty of Medicine and Dentistry, Palacký University Olomouc) for statistical analysis and Dana Galuszková, MD, PhD (Department of Transfusion Medicine, University Hospital Olomouc), for help with the collection of control samples.

Supported by grant from the Czech Ministry of Health No.IGA NT 13576 and Palacky University grant LF 2013004.

\section{CONFLICT OF INTEREST STATEMENT}

Author's conflict of interest disclosure: The authors stated that there are no conflicts of interest regarding the publication of this article.

\section{REFERENCES}

1. Meinhardt G, Wendtner CM, Hallek M. Molecular pathogenesis of chronic lymphocytic leukemia: factors and signaling pathways regulating cell growth and survival. J Mol Med 1999;77:282-93.

2. Ringshausen I, Schneller F, Bogner C, Hipp S, Duyster J, Peschel C, Decker T. Constitutively activated phosphatidylinositol-3 kinase (PI$3 \mathrm{~K}$ ) is involved in the defect of apoptosis in B-CLL: association with protein kinase Cdelta. Blood 2002;100:3741-8.

3. Messmer BT, Messmer D, Allen SL, Kolitz JE, Kudalkar P, Cesar D, Murphy EJ, Koduru P, Ferrarini M, Zupo S, Cutrona G, Damle RN, Wasil T, Rai KR, Hellerstein MK, Chiorazzi N. In vivo measurements document the dynamic cellular kinetics of chronic lymphocytic leukemia B cells. J Clin Invest 2005;115:755-64.

4. Hamblin TJ, Davis Z, Gardiner A, Oscier DG, Stevenson FK. Unmutated $\lg \mathrm{V}(\mathrm{H})$ genes are associated with a more aggressive form of chronic lymphocytic leukemia. Blood 1999;94:1848-54.

5. Damle RN, Wasil T, Fais F, Ghiotto F, Valetto A, Allen SL, Buchbinder A, Budman D, Dittmer K, Kolitz J, Lichtman SM, Schulman P, Vinciguerra VP, Rai KR, Ferrarini M, Chiorazzi N. Ig V gene mutation status and CD38 expression as novel prognostic indicators in chronic lymphocytic leukemia. Blood 1999;94:1840-7.

6. Crespo M, Bosch F, Villamor N, Bellosillo B, Colomer D, Rozman M, Marcé S, López-Guillermo A, Campo E, Montserrat E. ZAP-70 expression as a surrogate for immunoglobulin-variable-region mutations in chronic lymphocytic leukemia. N Engl J Med 2003;348:1764-75.

7. Rassenti LZ, Huynh L, Toy TL, Chen L, Keating MJ, Gribben JG, Neuberg DS, Flinn IW, Rai KR, Byrd JC, Kay NE, Greaves A, Weiss A, Kipps TJ. ZAP-70 compared with immunoglobulin heavy-chain gene mutation status as a predictor of disease progression in chronic lymphocytic leukemia. N Engl J Med 2004;351:893-901.

8. Döhner H, Stilgenbauer S, Benner A, Leupolt E, Krober A, Bullinger L, Döhner K, Bentz M, Lichter P. Genomic aberrations and survival in chronic lymphocytic leukemia. N Engl J Med 2000;343:1910-6.

9. Chen CZ, Li L, Lodish HF, Bartel DP. MicroRNAs modulate hematopoietic lineage differentiation. Science 2004;303:83-6.

10. Ambros V. MicroRNA pathways in flies and worms: growth, death, fat, stress, and timing. Cell 2003;113:673-6.

11. Bartel DP. MicroRNAs: genomics, biogenesis, mechanism, and function. Cell 2004;116: 281-97.

12. Valencia-Sanchez MA, Liu J, Hannon GJ, Parker R. Control of translation and mRNA degradation by miRNAs and siRNAs. Genes Dev 2006;20:515-24.

13. Lewis BP, Burge CB, Bartel DP. Conserved seed pairing, often flanked by adenosines, indicates that thousands of human genes are microRNA targets. Cell 2005;120:15-20.

14. Croce CM. Causes and consequences of microRNA dysregulation in cancer. Nat Rev Genet 2009;10:704-14.

15. Calin GA, Dumitru CD, Shimizu M, Bichi R, Zupo S, Noch E, Aldler H, Rattan S, Keating M, Rai K, Rassenti L, Kipps T, Negrini M, Bullrich F, Croce CM. Frequent deletions and downregulation of microRNA genes miR15 and miR16 at 13q14 in chronic lymphocytic leukemia. Proc Natl Acad Sci USA 2002;99:15524-9.

16. Garg R, Wierda W, Ferrajoli A, Abruzzo L, Pierce S, Lerner S, Keating $\mathrm{M}, \mathrm{O}$ 'Brien S.The prognostic difference of monoallelic versus biallelic deletion of $13 q$ in chronic lymphocytic leukemia. Cancer 2011;118:3531-7.

17. Cimmino A, Calin GA, Fabbri M, lorio MV, Ferracin M, Shimizu M, Wojcik SE, Aqeilan RI, Zupo S, Dono M, Rassenti L, Alder H, Volinia S, Liu CG, Kipps TJ, Negrini M, Croce CM. miR-15 and miR16 induce apoptosis by targeting BCL2. Proc Natl Acad Sci USA 2005;102:13944-9.

18. Fulci V, Chiaretti S, Goldoni M, Azzalin G, Carucci N, Tavolaro S, Castellano L, Magrelli A, Citarella F, Messina M, Maggio R, Peragine N, Santangelo S, Mauro R, Landgraf P, Tzuschl T, Weir DB, Chien M, 
Russo JJ, Ju J, Sheridan R, Sander C, Zavolan M, Guarini A, Foà R, Macino G. Quantitative technologies establish a novel microRNA profile of chronic lymphocytic leukemia. Blood 2007;109:4944-51.

19. Quillette P, Erba H, Kujawski L, Kaminski M, Shedden K, Malek SN Integrated genomic profiling of chronic lymphocytic leukemia identifies subtypes of deletion 13q14. Cancer Res 2008;68:1012-21.

20. Klein U, Lia M, Crespo M, Siegel R, Shen Q, Mo T, Ambesi-Impiombato A, Califano A, Migliazza A, Bhagat G, Dall-Favera R. The DLEU2/miR $15 \mathrm{a} / 16-1$ cluster controls $B$ cell proliferation and its deletion leads to chronic lymphocytic leukemia. Cancer Cell 2010;17:28-40.

21. Liu Q, Fu H, Sun F, Zhang H, Tie Y, Zhu J, Xing R, Sun Z, Zheng X. miR16 family induces cell cycle arrest by regulating multiple cell cycle genes. Nucl Acids Res 2008;36:5391-404.

22. ISCN 2009. An International System for Human Cytogenetic Nomenclature. Karger S: Basel 2009.

23. Pfaffl MW. A new mathematical model for relative quantification in real-time RT-PCR. Nucl Acids Res 2001;29:e45.

24. Butler T, Gribben JG. Biologic and clinical significance of molecular profiling in chronic lymphocytic leukemia. Blood Reviews 2010;24:135-41.

25. Oscier DG, Gardiner AC, Mould SJ, Glide S, Davis ZA, Ibbotson RE, Corcoran MM, Chapman RM, Thomas PW, Copplestone JA, Orchard JA, Hamblin TJ. Multivariate analysis of prognostic factors in CLL: clinical stage, IGVH gene mutational status, and loss or mutation of the p53 gene are independent prognostic factors. Blood 2002;100:1177-84.

26. Juliusson G, Oscier DG, Fitchett M, Ross FM, Stockdill G, Mackie MJ, Parker AC, Castoldi GL, Guneo A, Knuutila S, Elonen E, Gahrton G. Prognostic subgroups in B-cell chronic lymphocytic leukemia defined by specific chromosomal abnormalities. $N$ Engl J Med 1990;323:720-4.

27. Sampath D, Liu C, Vasan K, Sulda M, Puduvalli VK, Wierda WG, Keating MJ. Histone deacetylases mediate the silencing of miR$15 a$, miR-16, and miR-29b in chronic lymphocytic leukemia. Blood 2012;119:1162-72.

28. Lagos-Quintana M, Rauhut R, Lendeckel W, Tuschl T. Identification of novel genes coding for small expressed RNAs. Science 2001;294:853-8
29. Mourelatos Z, Dostie J, Paushkin S, Sharma A, Charroux B, Abel L, Rappsilber J, Mann M, Dreyfuss G. miRNPs: A novel class of ribonuc leoproteins containing numerous microRNAs. Genes Dev 2002;16:720-8.

30. Zhang L, Huang J, Yang N, Greshock J, Megraw MS, Giannakakis A, Liang S, Naylor TL, Barchetti A, Ward MR, Yao G, Medina A, O'BrienJenkins A, Katsaros D, Hatzigeorgiou A, Gimotty PA, Weber BL, Coukos $\mathrm{G}$. microRNAs exhibit high frequency genomic alterations in human cancer. Proc Natl Acad Sci USA 2006;103:9136-41.

31. Calin GA, Sevignani C, Dan Dumitru C, Hyslop T, Noch E, Yendamuri S, Shimizu M, Rattan S, Bullrich F, Negrini M, Croce CM. Human microRNA genes are frequently located at fragile sites and genomic regions involved in cancers. Proc Natl Acad Sci USA 2004;101:29993004.

32. Calin GA, Liu CG, Sevignani C, Ferracin M, Felli N, Dumitru CD, Shimizu M, Cimmino A, Zupo S, Dono M, Dell'Aquila ML, Alder H, Rassenti L, Kipps T J, Bullrich F, Negrini M, Croce CM. MicroRNA profiling reveals distinct signatures in $B$ cell chronic lymphocytic leukemias. Proc Natl Acad Sci USA 2004;101:11755-60.

33. Calin GA, Ferracin M, Cimmino A, Di Leva G, Shimizu M, Wojcik SE, Iorio MV, Visone R, Sever NI, Fabbri M, luliano R, Palumbo T, Pichiorri F, Roldo C, Garzon R, Sevignani C, Rassenti L, Alder H, Volinia S, Liu CG, Kipps TJ, Negrini M, Croce CM. A microRNA signature associated with prognosis and progression in chronic lymphocytic leukemia. $\mathrm{N}$ Engl J Med 2005;353:1793-801.

34. Zhang B, Pan X, Cobb GP, Anderson TA. microRNAs as oncogenes and tumor suppressors. Dev Biol 2007;302:1-12.

35. Wang M, Tan LP, Dijkstra MK, van Lom K, Robertus JL, Harms G, Blokzijl T, Kooistra K, van T'veer MB, Rosati S, Visser L, JongenLavrencic M, Kluin PM, van den Berg A. miRNA analysis in B-cell chronic lymphocytic leukaemia: proliferation centres characterized by low miR-150 and high BIC/miR-155 expression. J Pathol 2008;215:13-20.

36. Sandhu SK, Croce CM, Garzon R. Micro-RNA expression and function in lymphomas. Adv Hematol 2011;2011:347137. 